\title{
PEMBUATAN SISTEM INFORMASI PERPUSTAKAAN UNTUK MEMUDAHKAN PENGATURAN SIRKULASI BUKU PADA SMP NEGERI 13 SURAKARTA.
}

\author{
Ahmad Rozin ${ }^{1}$ \\ Dandi Katerpilarifai \\ Ahyana Ilham Wibisono ${ }^{3}$ \\ Dedi Gunawan ${ }^{4 *}$ \\ Program studi Informatika \\ Universitas Muhammadiyah Surakarta \\ 1'L200170135@ums.ac.id \\ 2L200170168@ums.ac.id \\ ${ }^{3}$ L200170170@ums.ac.id \\ 4dedi.gunawan@ums.ac.id
}

\begin{abstract}
ABSTRAK
Perpustakaan merupakan bagian dari sumber belajar yang harus dimiliki oleh setiap sekolah atau perguruan tinggi, karena peserta didik dengan mudah mendapatkan informasi atau ilmu pengetahuan melalui perpustakaan. Dengan adanya perkembangan teknologi membuat manusia berfikir untuk dapat bekerja lebih efektif dan efisien. Salah satunya yaitu dengan membuat sistem yang terkomputerisasi. Dengan memanfaatkan fasilitas website yang terhubung ke internet, perpustakaan dapat lebih efektif dan efisien dalam pencarian buku yang diperlukan. Pada project ini dirancang suatu sistem informasi berbasis web menggunakan bahasa pemrograman PHP MysSQL. Dengan sistem ini, diharapkan mampu mengatasi berbagai kebutuhan dari pengguna untuk mencari buku serta memudahkan administrasi sekolah dalam sirkulasi peminjaman buku dan pembuatan laporan bulanan. Disini penulis implementasikan kedalam Perancangan Sistem Informasi Perpustakaan SMP Negeri 13 Surakarta.
\end{abstract}

KATA KUNCI: Perpustakaan, PHP MySQL, Sistem Informasi, Web

\section{PENDAHULUAN}

Pengetahuan tidak hanya diperoleh dengan pengalaman secara nyata akan tetapi dapat didapatkan dari informasi yang diterima. Informasi dapat didapat dengan berbagai media, salah satunya dengan membaca buku yang terdapat pada perpustakaan. Hal ini sesuai dengan fungsi perpustakaan yaitu sebagai tempat menyimpan, mengolah, menyajikan, dan menyebarluaskan pengetahuan. Perpustakaan adalah suatu kesatuan unit kerja yang terdiri dari beberapa bagian yaitu, bagian pengembangan, bagian pengolahan koleksi, bagian pelayanan pengguna, dan bagian pemeliharaan sarana dan prasarana.

Dengan adanya perkembangan teknologi membuat manusia berfikir untuk dapat bekerja lebih efektif dan efisien. Salah satunya yaitu membuat sistem konvensional menjadi sistem yang terkomputerisasi. Dengan menggunakan sistem yang terkomputerisasi dapat membuat pekerjaan menjadi lebih mudah karena hampir semua sistem terkomputerisasi adalah suatu sistem yang siap untuk digunakan.

SMP Negeri 13 Surakarta merupakan salah satu sekolah negeri yang terdapat di kota surakarta. Berdasarkan observasi kami perpustakaan SMP Negeri 13 Surakarta masih menggunakan sistem konvensional dalam melakukan peminjaman buku, pendataan buku, dan rekapitulasi peminjam buku perbulan, sehingga rentan terjadinya kesalahan data akibat dari dokumentasi yang kurang baik. Hal ini seharusnya dapat diatasi dengan menggunakan sistem informasi perpustakaan berbasis website, karena dengan adanya sistem informasi berbasis website diharapkan pengelolaan data perpustakaan dapat lebih efektif dan efisien sehingga sirkulasi peminjaman buku dan data peminjam per bulan dapat terdokumentasi dengan baik.

\section{URAIAN KEGIATAN PENGABDIAN}

Pada kegiatan pengabdian ini ada beberapa tahapang yang dilakukan yaitu mengidentifikasi masalah yang dihadapi oleh mitra, menentukan bahan ataupun perlengkapan untuk menyelesaikan permasalahan mitra dan selanjutnya merancang solusi untuk memecahkan permasalahan.

\section{a. Web Browser}

\section{A. Perlengkapan dan bahan}

Web Browser merupakan perangkat lunak yang berfungsi untuk menerima dan menyajikan sumber informasi di internet. Mudahnya, browser digunakan untuk menampilkan halaman-halaman web. [1].

b. Bahasa pemrograman untuk web

Untuk membuat suatu system informasi berbasis web, beberapa Bahasa pemrograman yang 
umum digunakan adalah PHP, HTML, CSS dan JavaScritp. PHP merupakan salah satu bahasa pemrograman berbasis web yang ditulis oleh dan untuk pengembang web. PHP pertama kali dikembangkan oleh Rasmus Lerdorf, seorang pengembang software dan anggota tim Apache, dan dirilis pada akhir tahun 1994 [2].

HTML merupakan singkatan dari Hypertext Markup Language, dikembangkan pertama kali oleh tim Berners-Lee bersama dengan protokol HTTP pada tahun 1989. Tujuan utama pengembangan HTML adalah untuk menghubungkan satu halaman web dengan halaman web lainnya. HTML merupakan bahasa dasar web yang berfungsi untuk menampilkan berbagai komponen web. Sementara itu, untuk mempercantik tampilan web, dikembangkanlah CSS atau Cascading Style. CSS pertama kali diusulkan oleh Hakon Wium Lie pada tahun 1994 dan selanjutnya distandarisasi oleh W3C. Selain HTML dan CSS, sebuah aplikasi berbasis web tidak dapat dilepaskan dari teknologi Javascript. Pertama kali Javascript dikembangkan oleh Netspace dengan nama LiveScript. Fungsi utama dari Javascript adalah untuk menambah fungsionalitas dan kenyamanan halaman web [3].

\section{c. Server basisdata}

Server basisdata atau Database Server merupakan sebuah server yang berisi perangkat lunak yang melayani pengelolaan basisdata bagi suatu program atau komputer lainnya. Pada umumnya server basisdata dapat diakses melalui mekanisme client-server. Server basisdata dapat terdiri dari satu atau beberapa perangkat lunak sistem manajemen basis data atau database management system (DMBS). DBMS merupakan suatu perangkat lunak yang memungkinkan user (pengguna) untuk membuat, memelihara, mengontrol dan mengakses basisdata secara praktis dan efisien [4].

\section{d. Editor Bahasa pemrograman}

Editor Bahasa pemrogaman atau sering disebut sebagai Integrated Development Environment (IDE), merupakan sebuah perangkat lunak untuk menuliskan perintah-perintah program, serta mempermudah penggunanya dalam membuat program [5].

\section{PERANCANGAN SISTEM}

A. Desain Sistem

1. Use Case Diagram

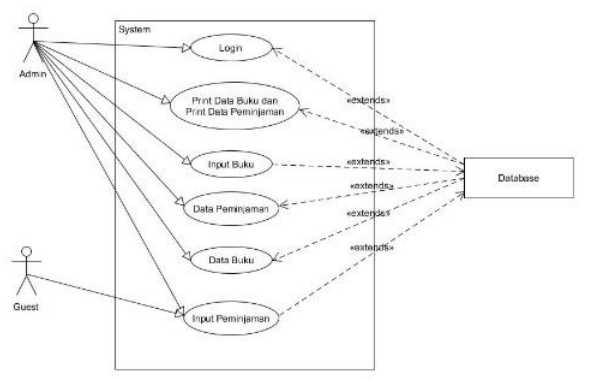

Gambar 1. Use Case Diagram

2. Skema Database

Entity Relationship Diagram harus diramcang sebaik mungkin untuk mendukung kelancaran sistem [6]. Tabel yang berelasi atau berhubungan akan mempermudah programmer untuk menentukan fungsi tiap kolom tabel tersebut.

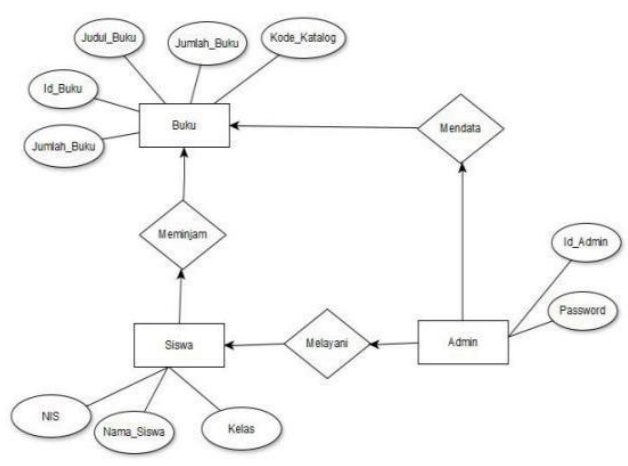

Gambar 2. Skema Entity Relationship Diagram (ERD)

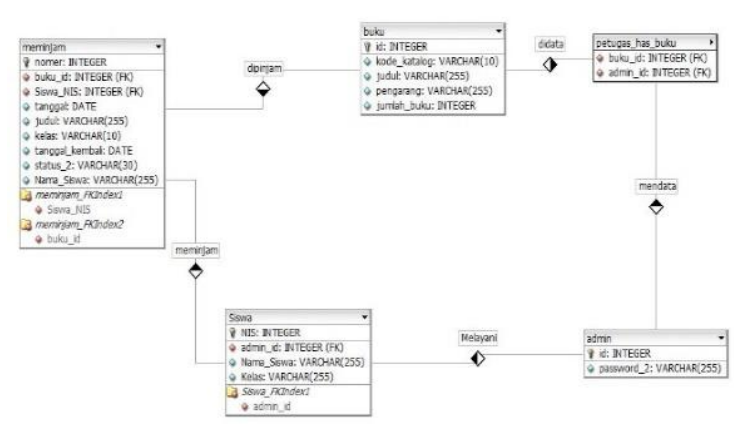

Gambar 3. Skema Fisik

B. Desain Interface

\section{Login}

Pada bagian ini terdapat laman login yang berfungsi sebagai tanda masuk bagi user dan admin 


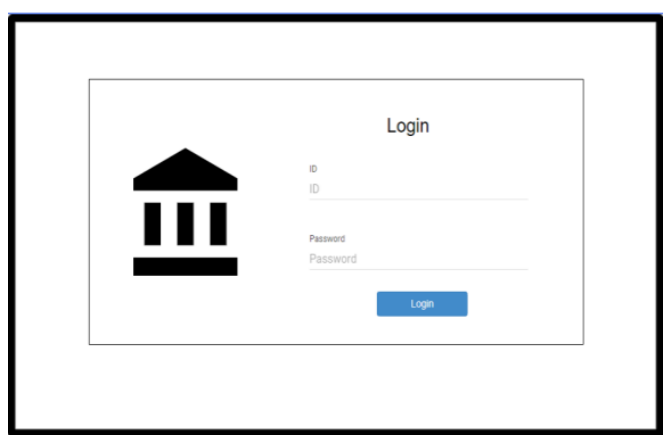

Gambar 4. Desain Tampilan Login

2. Form Peminjaman

Laman peminjaman ini digunakan untuk mempermudah siswa dalam melakukan peminjaman buku diperpustakaan yang ditandai dengan pengisian formulir peminjaman

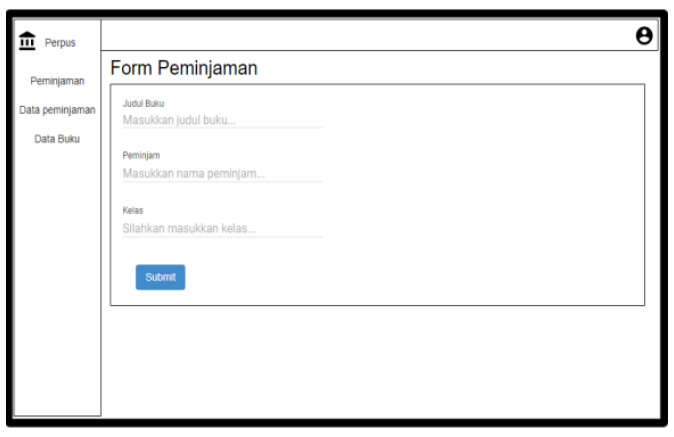

Gambar 5. Desain Tampilan Form Peminjaman

\section{Data peminjaman}

Data ini memiliki informasi mengenai lama peminjaman buku yang disertai tanggal peminjaman dan tanggal pengembalian buku

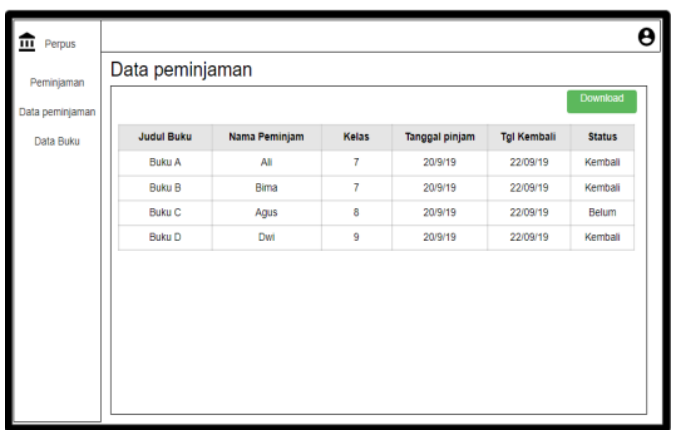

Gambar 6. Desain Tampilan Data Peminjaman

4. Data buku

Terdapat informasi mengenai jenis-jenis buku yang terdapat diperpustakaan dan data buku tersebut dapat diganti oleh admin jika mengalami kekeliruan

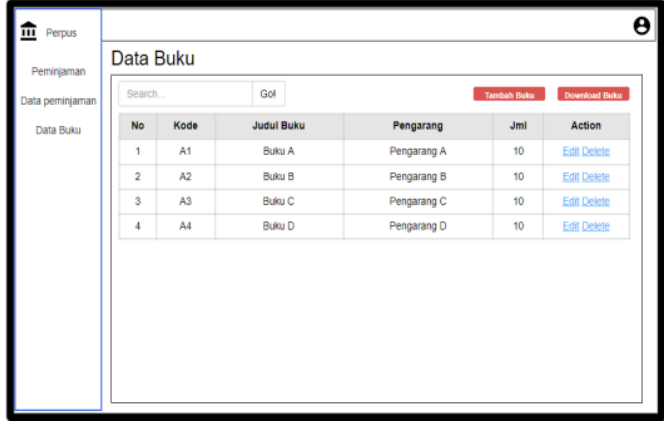

Gambar 7. Desain Tampilan Data Buku

\section{HASIL DAN PENGUJIAN SISTEM INFORMASI}

Setelah melakukan perancangan proses selanjutnya adalah mengimplementasikan hasil rancangan ke dalam Bahasa pemrograman. Berikut ini adalah beberapa hasil dari implementasi rancangan sistem.

\section{Halaman Login}

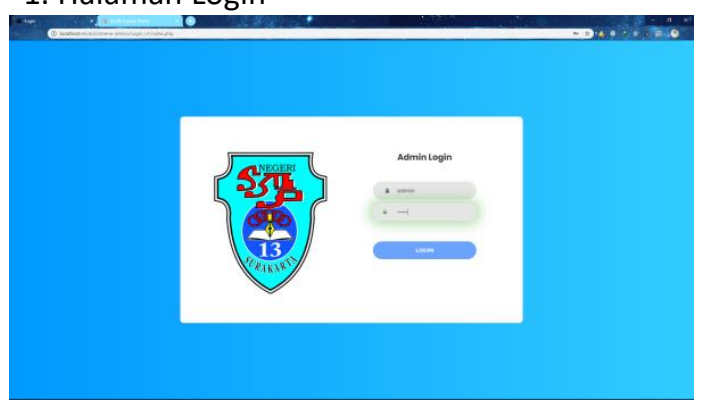

Gambar 1.Hasil Tampilan Login

2.Tampilan Peminjaman

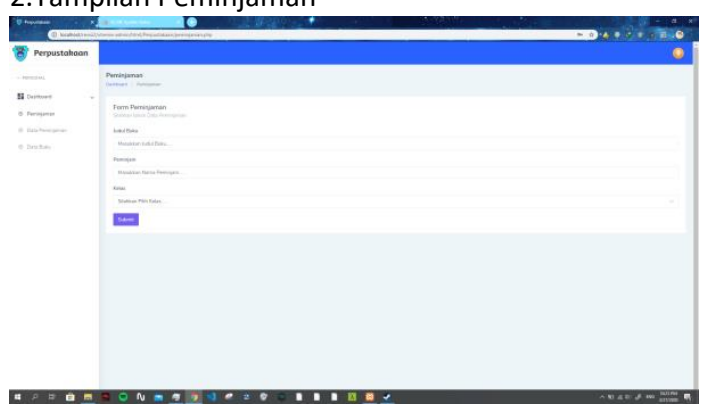

Gambar 2. Hasil Tampilan Peminjaman

3.Tampilan Data Peminjaman

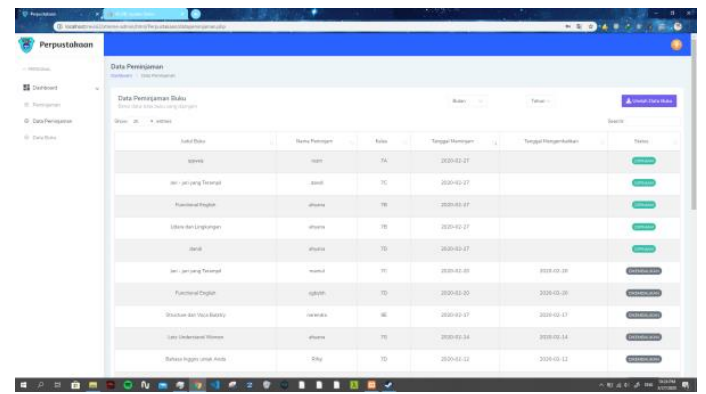

Gambar 3. Hasil Tampilan Data Peminjaman 
4.Tampilan Data Buku

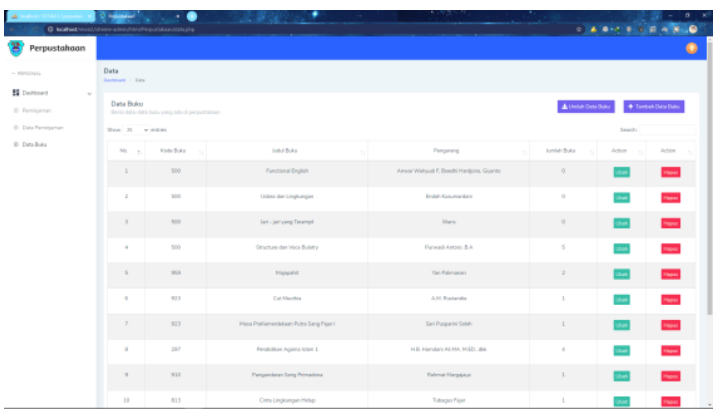

Gambar 4. Desain Tampilan Data Buku

5.Tampilan Edit Buku

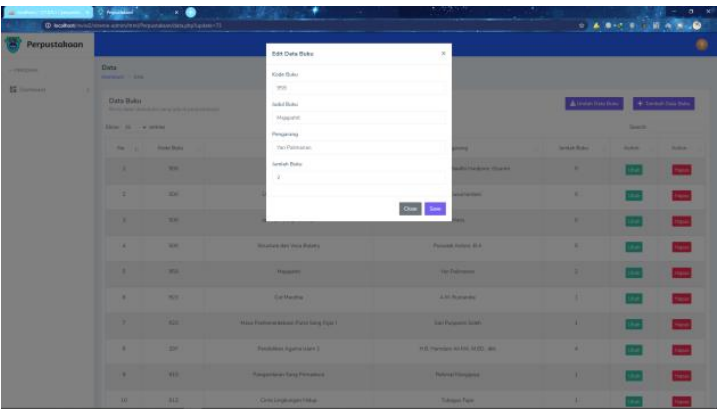

Gambar 5. Hasil Tampilan Edit Data Buku

6.Tampilan Tambah Buku

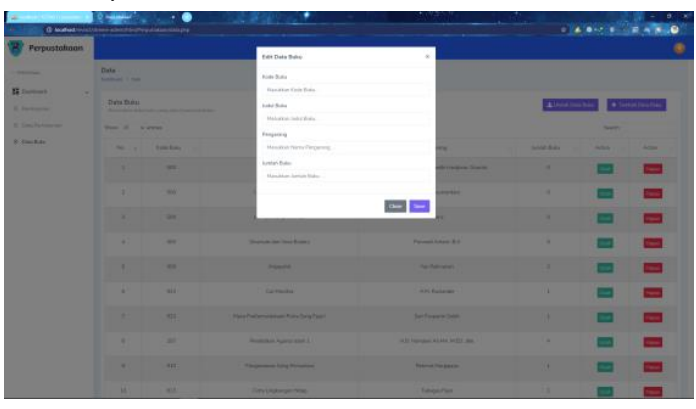

Gambar 6. Hasil Tampilan Tambah Data Buku

Untuk memastikan hasil implementasi hasil rancangan berjalan sesuai kami beberapa pengujian dengan metode blackbox [7]. Hasil dari pengujian dijelaskan pada Tabel 1.
Tabel 1. Pengujian sistem

\begin{tabular}{|c|c|c|c|c|}
\hline $\begin{array}{l}\text { Test } \\
\text { case }\end{array}$ & $\begin{array}{c}\text { Test Case } \\
\text { Description }\end{array}$ & $\begin{array}{l}\text { Expected } \\
\text { Result }\end{array}$ & $\begin{array}{l}\text { Actual } \\
\text { Result }\end{array}$ & Status \\
\hline \multirow[t]{6}{*}{$\begin{array}{l}\text { Test } \\
\text { Fungsi } \\
\text { Login }\end{array}$} & \multirow[t]{3}{*}{$\begin{array}{l}\text { Memastikan } \\
\text { fungsi login } \\
\text { dengan } \\
\text { username } \\
\text { dan password } \\
\text { benar }\end{array}$} & $\begin{array}{l}\text { Melihat } \\
\text { halaman login }\end{array}$ & $\begin{array}{l}\text { Sesuai } \\
\text { harapan }\end{array}$ & Pass \\
\hline & & $\begin{array}{l}\text { Dapat } \\
\text { melanjutkan } \\
\text { proses login }\end{array}$ & $\begin{array}{l}\text { Sesuai } \\
\text { harapan }\end{array}$ & Pass \\
\hline & & $\begin{array}{l}\text { Pengguna } \\
\text { dapat login }\end{array}$ & $\begin{array}{l}\text { Penggun } \\
\text { a sukses } \\
\text { login }\end{array}$ & Pass \\
\hline & $\begin{array}{l}\text { Memastikan } \\
\text { fungsi login } \\
\text { dengan } \\
\text { username } \\
\text { benar dan } \\
\text { password } \\
\text { salah }\end{array}$ & $\begin{array}{l}\text { Melihat } \\
\text { halaman login }\end{array}$ & $\begin{array}{l}\text { Sesuai } \\
\text { harapan }\end{array}$ & Pass \\
\hline & & $\begin{array}{l}\text { Dapat } \\
\text { melanjutkan } \\
\text { proses login }\end{array}$ & $\begin{array}{l}\text { Sesuai } \\
\text { harapan }\end{array}$ & Pass \\
\hline & & $\begin{array}{l}\text { Pengguna } \\
\text { gagal login }\end{array}$ & $\begin{array}{l}\text { Penggun } \\
\text { a gagal } \\
\text { melakuka } \\
\mathrm{n} \text { login }\end{array}$ & Pass \\
\hline \multirow[t]{5}{*}{$\begin{array}{l}\text { Test } \\
\text { Fungsi } \\
\text { Print } \\
\text { Data } \\
\text { Buku } \\
\text { dan } \\
\text { Print } \\
\text { Data } \\
\text { Pemin } \\
\text { jaman }\end{array}$} & $\begin{array}{l}\text { Memastikan } \\
\text { fungsi print } \\
\text { data buku }\end{array}$ & $\begin{array}{l}\text { Dapat } \\
\text { melihat } \\
\text { halaman data } \\
\text { buku }\end{array}$ & $\begin{array}{l}\text { Sesuai } \\
\text { harapan }\end{array}$ & Pass \\
\hline & & $\begin{array}{l}\text { Data buku } \\
\text { berhasil } \\
\text { diunduh }\end{array}$ & $\begin{array}{l}\text { Data } \\
\text { buku } \\
\text { berhasil } \\
\text { diunduh }\end{array}$ & Pass \\
\hline & $\begin{array}{l}\text { Memastikan } \\
\text { fungsi print } \\
\text { data } \\
\text { peminjaman }\end{array}$ & $\begin{array}{l}\text { Dapat } \\
\text { melihat } \\
\text { halaman } \\
\text { peminjaman }\end{array}$ & $\begin{array}{l}\text { Sesuai } \\
\text { harapan }\end{array}$ & Pass \\
\hline & & $\begin{array}{l}\text { Melanjutkan } \\
\text { ke proses } \\
\text { pengunduhan } \\
\text { data } \\
\text { peminjaman }\end{array}$ & $\begin{array}{l}\text { Sesuai } \\
\text { harapan }\end{array}$ & Pass \\
\hline & & $\begin{array}{l}\text { Data } \\
\text { peminjaman }\end{array}$ & $\begin{array}{l}\text { Data } \\
\text { peminja } \\
\text { man }\end{array}$ & Pass \\
\hline
\end{tabular}




\begin{tabular}{|c|c|c|c|c|}
\hline & & $\begin{array}{l}\text { berhasil } \\
\text { diunduh }\end{array}$ & $\begin{array}{l}\text { berhasil } \\
\text { di unduh }\end{array}$ & \\
\hline \multirow[t]{4}{*}{$\begin{array}{l}\text { Test } \\
\text { Fungsi } \\
\text { Input } \\
\text { Buku }\end{array}$} & $\begin{array}{l}\text { Memastikan } \\
\text { fungsi input } \\
\text { buku }\end{array}$ & $\begin{array}{l}\text { Dapat } \\
\text { melihat } \\
\text { halaman data } \\
\text { buku }\end{array}$ & $\begin{array}{l}\text { Sesuai } \\
\text { harapan }\end{array}$ & Pass \\
\hline & & $\begin{array}{l}\text { Muncul form } \\
\text { input data } \\
\text { buku }\end{array}$ & $\begin{array}{l}\text { Sesuai } \\
\text { harapan }\end{array}$ & Pass \\
\hline & & $\begin{array}{l}\text { Dapat } \\
\text { melanjutkan } \\
\text { proses input }\end{array}$ & $\begin{array}{l}\text { Sesuai } \\
\text { harapan }\end{array}$ & Pass \\
\hline & & $\begin{array}{l}\text { Data buku } \\
\text { berhasil } \\
\text { ditambahkan }\end{array}$ & $\begin{array}{l}\text { Data } \\
\text { buku } \\
\text { berhasil } \\
\text { ditambah } \\
\text { kan }\end{array}$ & Pass \\
\hline \multirow[t]{2}{*}{$\begin{array}{l}\text { Test } \\
\text { Fungsi } \\
\text { Data } \\
\text { Pemin } \\
\text { jaman }\end{array}$} & \multirow[t]{2}{*}{$\begin{array}{l}\text { Memastikan } \\
\text { Pengontrolan } \\
\text { data } \\
\text { peminjaman } \\
\text { berfungsi } \\
\text { normal }\end{array}$} & $\begin{array}{l}\text { Dapat } \\
\text { melihat } \\
\text { halaman data } \\
\text { peminjaman } \\
\text { dan } \\
\text { menampilkan } \\
\text { data-data } \\
\text { buku dengan } \\
\text { status } \\
\text { dipinjam } \\
\text { maupun telah } \\
\text { dikembalikan }\end{array}$ & $\begin{array}{l}\text { Sesuai } \\
\text { harapan }\end{array}$ & Pass \\
\hline & & $\begin{array}{l}\text { Tombol pada } \\
\text { status yang } \\
\text { semula } \\
\text { dipinjam } \\
\text { menjadi } \\
\text { status sudah } \\
\text { dikembalikan }\end{array}$ & $\begin{array}{l}\text { Sesuai } \\
\text { harapan }\end{array}$ & Pass \\
\hline \multirow[t]{4}{*}{$\begin{array}{l}\text { Test } \\
\text { Fungsi } \\
\text { Data } \\
\text { Buku }\end{array}$} & $\begin{array}{l}\text { Memastikan } \\
\text { Pengontrolan } \\
\text { data buku } \\
\text { inventaris }\end{array}$ & $\begin{array}{l}\text { Dapat } \\
\text { melihat } \\
\text { halaman data } \\
\text { buku lalu } \\
\text { muncul } \\
\text { seluruh data } \\
\text { buku yang } \\
\text { ada }\end{array}$ & $\begin{array}{l}\text { Sesuai } \\
\text { harapan }\end{array}$ & Pass \\
\hline & \multirow[t]{3}{*}{$\begin{array}{l}\text { Memastikan } \\
\text { fungsi } \\
\text { merubah } \\
\text { data buku }\end{array}$} & $\begin{array}{l}\text { Dapat } \\
\text { melihat } \\
\text { halaman data } \\
\text { buku lalu } \\
\text { muncul } \\
\text { seluruh data } \\
\text { buku yang } \\
\text { ada }\end{array}$ & $\begin{array}{l}\text { Sesuai } \\
\text { harapan }\end{array}$ & Pass \\
\hline & & $\begin{array}{l}\text { Muncul form } \\
\text { untuk } \\
\text { merubah } \\
\text { data buku }\end{array}$ & $\begin{array}{l}\text { Sesuai } \\
\text { harapan }\end{array}$ & Pass \\
\hline & & $\begin{array}{l}\text { Dapat } \\
\text { menginputka } \\
\text { n data buku } \\
\text { yang baru }\end{array}$ & $\begin{array}{l}\text { Sesuai } \\
\text { harapan }\end{array}$ & Pass \\
\hline
\end{tabular}

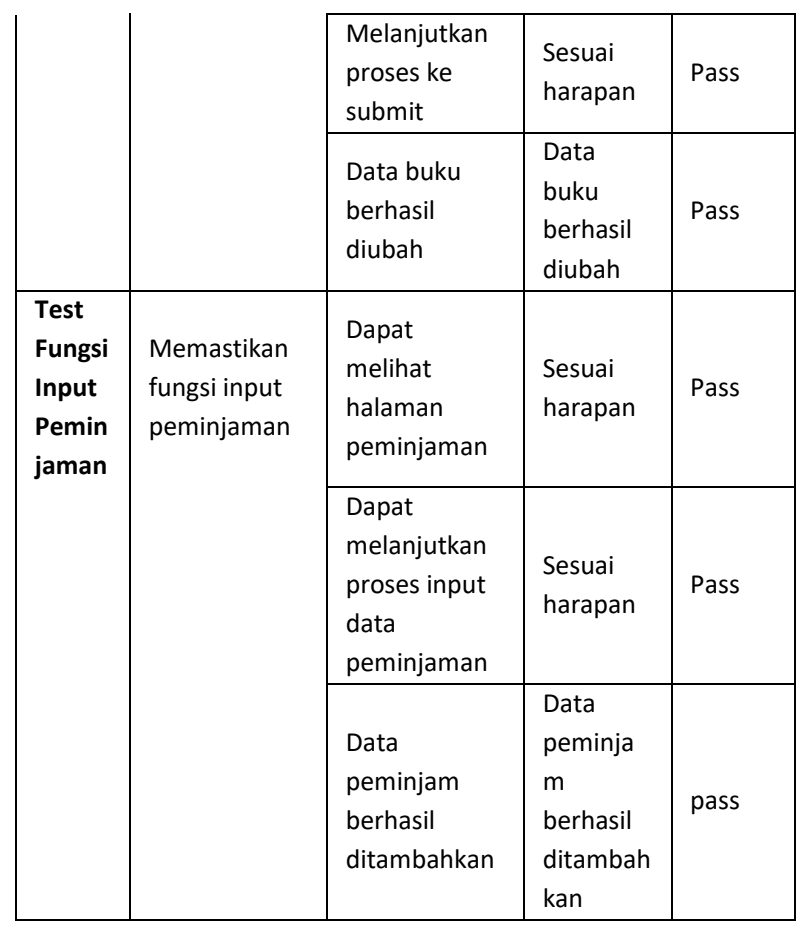

\section{KESIMPULAN}

Sistem informasi perpustakaan ini dikembangkan berdasarkan kebutuhan SMP Negeri 13 Surakarta dengan melakukan wawancara kepada beberapa pihak sehingga mampu mendukung seluruh kegiatan perpustakaan agar lebih efektif dan efisien, sehingga proses akademik yang dilakukan di lingkungan perpustakaan mendapat peningkatan

\section{DAFTAR PUSTAKA}

[1] Solichin, Achmad, "Pengantar Pemrograman Web," Permrograman Web dengan PHP dan MySQL, 2016.

[2] https://dapo.dikdasmen.kemdikbud.go.id/sekol ah/e4f966932b5a8e9650fd

[3] Aryanto, A., \& Irianto, T. (2013). Pembuatan Sistem Informasi Perpustakaan Smp Muhammadiyah 7 Surakarta. Journal Speed Sentra Penelitian Engineering Dan Edukasi, Vol 5 No 1, 15-20.

[4] Nugraha, F. (2014). Analisa Dan Perancangan Sistem Informasi Perpustakaan. Jurnal SIMETRIS, Vol 5 No 1, 27-32. 
[5] Maryono, Y., \& Darwati, I. (2017). Perancangan Web Perpustakaan Pada SMP Taruna Bhakti Depok. Jurnal Pilar Nusa Mandiri, 13(2), 239244. $\quad$ Retrieved from http://ejournal.nusamandiri.ac.id/ejurnal/index. $\mathrm{php} /$ pilar/article/view/501

[6] Dari, D. W., Sari, A. O., \& Astrilyana, A. (2018). Laporan Akhir Penelitian. Jakarta.

[7] Abednego, Dewi, L. P., \& Wibowo, A. (2017). Perancangan dan Pembuatan Sistem Informasi Perpustakaan Berbasis Web pada SMP YBPK 1 Surabaya. Jurnal Infra, Vol 5 No 1, 199-204. 